\title{
Politeness principle and its implication in EFL classroom in Indonesia
}

\author{
Haryanto - Sukardi Weda - Nashruddin
}

DOI: 10.18355/XL.2018.11.04.09

\begin{abstract}
This study explores the use of politeness principle by EFL teacher in term of the interaction between a teacher and students in learning process in the English as a Foreign Language (EFL) classroom at the VIII grade of SMP Negeri 23 Makassar, Indonesia based on Leech's theory about politeness principle, consists of six maxims, namely tact maxim, generosity maxim, approbation maxim, modesty maxim, agreement maxim, and sympathy maxim. Thus, the objectives of this research are (1) to find out the politeness principles used by the EFL teacher during the classroom interaction, and (ii) to find out the implication of politeness principles toward English teaching-learning process. This case study applies qualitative method, with the technique of data collection through observation and interview. Seven meetings of the classroom interaction between an EFL teacher and 38 students were observed. In the observation, the researchers used an audio recorder. The recording was transcribed and analyzed by making use of related politeness principles. Then, the EFL teacher and three randomly chosen students were interviewed. The result of observation shows that the EFL teacher used six maxims, namely tact maxim, generosity maxim, approbation maxim, modesty maxim, agreement maxim, and sympathy maxim. The data also show that in the classroom interaction, the teacher dominantly used tact maxim. In addition, the result of interview shows that politeness principle creates togetherness between a teacher and students, builds respect behavior of students, and helps students to have a positive attitude toward the lesson that obviously motivates them to participate more actively in the learning process.
\end{abstract}

Key words: politeness principle, classroom interaction, the implication

\section{Introduction}

Human beings communicate to convey messages and create social interaction. In conducting social interaction, people need a medium, namely language. Language has a role as a message conveyor among people. According to McMohan (1994) language is an arbitrary system of symbolic sounds, used by members of a society to cooperate, interact and identify themselves. In everyday life, people must use language to interact with one another.

In the classroom interaction, the strategies are necessary that govern the speaker and the hearer, so that later a good communication between them can be maintained. One of the examples is the expression of politeness. The speaker and the hearer carry out the strategy so that the communication runs well. Thus, after the communication process is completed, the speaker and the hearer gain the deep impression, that is, the polite impression.

Generally, politeness principle can be defined with an expression "just use as little as possible utterances that consist of impolite expressions" (Leech, 1983). An utterance is considered polite if the speaker uses polite words, does not govern directly, and respects for others.

Linguistic politeness is one of the studies in pragmatics. Austin (1962) presented the definition of pragmatics as the study of all aspects of linguistic attitudes. Pragmatics bridges the distance between the side of system language and the usage, and connect both at the same time. Greenfield (1972) defines pragmatics as meaning in interaction, which means that meaning is bound. Meaning is not something that is

XLinguae, Volume 11, Issue 4, October 2018, ISSN 1337-8384, eISSN 2453-711X 
inherent in the word itself, nor something that the speaker produces, nor just something that the listener comprehends. While according to Leech (1983) pragmatics is a study about how language is used in a particular context or situation. In line with Leech, Levinson (1983) defined pragmatics as a linguistics branch that studies the relation between language and the context.

One of studies in pragmatics is linguistic politeness. Lakoff (1973) defines politeness as an interpersonal relationship system designed to facilitate the interaction. A simple definition was put forward by Leech (1983), namely politeness is a behavior that is expressed in a good or ethical way. An utterance is generally considered polite if the speaker uses good words, respects others, and does not impose.

The theory of politeness which is now considered to be the most complete, most established, and relatively most comprehensive has been formulated by Leech (1983). Therefore, the basic concept adopted in this study is the theory of politeness principle developed by Leech. Leech divided politeness principle into six maxims, namely: tact maxim, generosity maxim, approbation maxim, modesty maxim, agreement maxim, and sympathy maxim.

The basic idea in tact maxim it is that the participants of the speech should always adhere to the principle of reducing their own profit and maximizing the other's profit in the communication (Safitri, 2014). A person who holds and practices tact maxim will be regarded as a polite person. Similarly, the instruction which is expressed indirectly is more polite than the one is spoken directly. Therefore, the more indirect a speech, the more polite it is. As an example which is modified from Safitri (2014), the expression "Close the window!" is direct instruction. Therefore it is less polite. While the utterance "Could you close the window, please?" or "Would you mind closing the window?" are considered more polite.

The purpose of generosity maxim is 'make your profit as little as possible; make your loss as big as possible' (Kurniawati, 2012). For example, in speech "You may use my umbrella," there is a disadvantage for the speaker and the benefit for the interlocutor. A higher level of politeness can be achieved if the listener is not mentioned as the giver, for example: "Can I have some sugar?" and even more polite if the speaker does not appear as a recipient, as in utterance "Is there some sugar?" (The examples are modified from Kurniawati (2012).

Approbation maxim is an attempt to avoid saying unpleasant things about others, more specifically, about the listener. For example, after a music show, a spectator would be considered polite if he/ she praised the artist's performance by saying, "He played very well," instead of saying, "That was a vapid musical performance."

In modesty maxim, the speech participants are expected to be humble by reducing the praise of them. For example, it can be seen in the following conversation:

Student A: Your answer is very excellent!

Student B: Oh, yes, it's me.

Student B is considered impolite because he maximizes praise on himself. On the contrary, if he replies, "Ah, I think it is ordinary," it is more polite, and it is the answer that is more expected by the listener than the first one.

In agreement maxim, it is emphasized that all speech participants speak to one another mutually appropriate or the compatibility is created among them in the communication. The implementation of agreement maxim can be seen in the following conversation (http://www.scribd.com/doc/14548085/pragmatik) which is translated from Indonesian to English.

Teacher 1: This room is dark, isn't it?

Teacher 2: Where is the light switch? 
In the example above, there is the same perception between teacher A and B that the room is dark. Teacher B agrees with the teacher A that the room is dark, so he asked: "Where is the light switch?"

In sympathy maxim, it is expected that all speech participants can maximize the attitude of sympathy with one another. Attitudes of antipathy towards others will be regarded as an act of impoliteness. People who are antipathic toward others, being cynical about others, will be considered impolite in society. Speech acts such as condolences and congratulation include the application of sympathy maxim. In the sympathy maxim, it is expected that if others get success or happiness, the speaker should give congratulation, as the following example: (http://www.scribd.com/doc/14548085/pragmatik) which is translated from Indonesian to English.

Student 1: I will take the final examination next week.

Student 2: Wow, good luck!

A study on the relationship between politeness and culture has been conducted by Kiyama, Tamaoka, and Takiura (2012) in Japan. Using a survey, the study aims to assess the differences between the politeness strategies used by Westerners and the politeness strategies employed by the Japanese. The results indicate that factors related to intrinsic charge and the attitude of the other person have greater influence than interpersonal and intrapersonal factors. The three researchers conclude that Brown and Levinson's politeness theory can be applied to non-Western cultures, especially Japan.

In the context of Indonesian culture, the research on linguistic politeness has been conducted by Achmad (2012), with the aim at studying, explaining, and exploring the linguistic forms and linguistic features of language politeness in Bugis Pinrang society. The research applied ethnomethodology method, with discourse analysis technique viewed from pragmatic, semiotic and concept of face want (Brown, Levinson, 1987). The results show the realization and implications of siri' as the basic values of ethics, language politeness, self-actualization, self-image, courage, solidarity, and cooperation in a society of Bugis Pinrang.

The research that was conducted by Pitts, Fowler, Fisher, and Smith (2013) was based on politeness theory of Face Threatening Act (Brown, Levinson, 1987) to reveal in what way children combine face work in imagined messages to start a conversation with their parents. Using the mixed method in their research, the researchers found that discussing future needs could threaten face. Therefore, a study of such conversational approaches by adult children is an important first step to understand what makes the conversation effective and supportive.

Schools as formal educational institutions have a strategic role in shaping student politeness. The success of the teaching and learning process in the school is determined by several factors. Teachers must have a lot of strategy in teaching. That aims at making students comfortable and enjoy (Jufri, Haryanto, Weda, 2015). One of the decisive factors is the application of the politeness principle between the student and the teacher, and among students and other students. Therefore, teachers and students should pay attention to politeness principle in communication.

The interaction between the teacher and students is believed to contribute to the development of the language of the students (Strike, Egan, 1978). Conflicts between teachers and students sometimes occur. Teachers are sometimes disillusioned with the behavior of students in the classroom and teachers find it difficult to control the condition.

Teaching and learning process, which involves teacher and students in a formal situation, is expected to guide students to behave politely. Teachers are 
expected to give a positive impact to the students' behavior through their verbal and nonverbal communication (Ulfa, Atmowardoyo, Mahmud, 2015). When the teacher is angry with the student, the student will be scared, and the teaching and learning process will not be successful. The interaction between the teacher and the student in the classroom should be kept in good relations.

Several researchers have also studied the politeness used by teachers in the context of education in Indonesia. Kurniawati (2012), in her research, used the qualitative descriptive method, collected data with conversation analysis technique, recording technique and noting technique. Data analysis used a pragmatic matching method, based on the indicators of linguistic politeness according to the theory proposed by Leech (1983). The result shows that the number of adherence of the politeness principle that occurs in class discussion activities is greater than the deviation. This is evidenced by data showing that the numbers of compliance of politeness principle in class discussion activities are 190 utterances, while the numbers of the deviation are 54 utterances.

In Japan, Kawai (2013) conducted a study of the relationship between the application of the theory of politeness to English education. The theoretical basis used in the research is the theory of politeness strategy (Brown, Levinson, 1987). The researcher applied the mixed method to collect the data. In summary, it is concluded that the low English language proficiency of Japanese students is caused by a lack of understanding of the theory of politeness. Furthermore, the results of the analysis of English textbooks conducted by the researcher, and the results of the interview with students, indicate a correlation between the lack of perspectives on politeness and the hesitancy to master cross-cultural communication.

Another research on the use of politeness in the teaching of English as a foreign language has been conducted by Sülü (2015). This study investigated a classroom in terms of interaction between English learners and a native English speaking teacher. The objective of the research was to observe whether the influence of politeness strategies was different if students and the teacher do not have the same culture and mother tongue. For collecting data, the researcher observed and recorded a learning activity that ran for two hours. The results show that politeness strategies are appearing in the English class help students to have positive feelings toward the lessons and motivate them to be more active in the classroom.

Eshghinejad and Moini (2016) also conducted a study to examine the politeness strategies used in text messaging between the lecturer and the English learner as a foreign language. The study aims to explain the strategies used by lecturers and learners of English as a foreign language, and to find out whether there is a significant difference between male and female students on the use of politeness strategies in sending an SMS to their professors, taking into account that there is a power relation and unequal social distance between them. The results show that lecturers use politeness strategies in writing text messages. The results also show that there is no significant difference between male and female students in using politeness strategies.

Another study to examine politeness in the context of EFL learning had been conducted by Nashruddin (2017) who focused on the study of politeness principle used by EFL teacher and the implication toward teaching and learning process. As the theoretical basis, the researcher adopted the theory of politeness principle proposed by Leech (1983). The findings of the qualitative study indicated that the EFL teacher used six maxims of the politeness principle in classroom interaction. The results also showed that the implication of politeness principle created togetherness between the teacher and the students, built respect behavior of the students, created cooperating interaction between the teacher and the students, helped students to have positive feelings towards the lesson and motivated them to participate more in learning. 
Considering those previous studies, it is believed that the application of the politeness principle in teaching can have a positive effect on students in classroom interactions. Therefore, the researcher conducted a similar study on the scope of the politeness principle used by an EFL teacher in class interaction. The objectives of this research are (1) to find out politeness principles used by EFL teacher in classroom interaction, (ii) to find out the implication of politeness principle toward teachinglearning process. The research was conducted in SMPN 23 Makassar, with applying the theory of politeness principle proposed by Leech (1983).

\section{Research Method}

Theoretically, a pragmatic approach is used in this research, while methodologically, a qualitative descriptive approach is used. The researcher tried to obtain data in the form of words, which were observed and analyzed based on the facts of existing data. As said by Moleong (2008) that the collected data is in the form of words, images, and not in numbers. This research is descriptive qualitative research with natural setting as a direct data source where the researcher took the role as the main instrument. Conversation Analysis (CA) - the study of talking-in-interaction - is the theoretical and methodological approach typically used to understand social life (Hyland, Paltridge, 2011).

To collect data, this case study involved only one teacher as a research subject. Other instruments used are an audio recorder, observation checklist, and an interview guide. Data collection was done by using qualitative data collection techniques, namely observation, and interview. The observation was done to know the real situation of the teaching process. The researcher observed the lessons in the classroom when they communicated. The researcher used an audio recorder to record the teaching and learning process. It continued until the researcher got saturated data. Observations were made in the classroom of VIII SMPN 23 Makassar. While recording, the researcher filled out the observation sheet. Then, the EFL teacher as a subject of research and some of the randomly chosen students of VIII class SMPN 23 Makassar have been interviewed. The purpose of the interview is to match the results of the observations with the informant's opinion. From here, the researcher found the implications of the politeness principle towards teaching and learning.

Data analysis is based on the theory of Miles and Huberman (1994), which consists of three concepts; data reduction, data display, and verification. Data reduction, which is to create a script based on recorded data and written data, select the data needed to answer research questions and remove unnecessary data, then identify the kind of politeness principles. Data display, i.e., making the relationship of politeness used and teaching English and learning, data displayed in written text. The final step is the conclusion or verification.

\section{Findings}

From the observation result for seven meetings and data analysis, there were 52 teacher's utterances that contained the politeness principle. The entire utterance, divided into the maxims of the politeness principles. The results of the observation checklist are shown in the following tables. 
Table 1. The Frequency of Occurrence of

Politeness Principle in the Teacher's Utterances

\begin{tabular}{|c|c|c|c|c|c|c|c|c|c|}
\hline $\mathrm{N}$ & \multirow{2}{*}{ Maxim } & \multicolumn{7}{|c|}{ Meeting } & \multirow{2}{*}{$\begin{array}{c}\text { Tota } \\
1\end{array}$} \\
\hline $\mathrm{o}$ & & I & II & III & IV & $\mathrm{V}$ & VI & VII & \\
\hline 1. & $\begin{array}{l}\text { Tact } \\
\text { Maxim }\end{array}$ & 2 & 3 & 2 & 3 & 3 & 2 & 3 & 18 \\
\hline 2. & $\begin{array}{l}\text { Approbation } \\
\text { Maxim }\end{array}$ & 3 & 2 & 1 & 3 & 2 & 3 & 2 & 16 \\
\hline 3. & $\begin{array}{l}\text { Generosity } \\
\text { Maxim }\end{array}$ & - & 1 & 1 & 2 & - & 2 & - & 6 \\
\hline 4. & $\begin{array}{l}\text { Modesty } \\
\text { Maxim }\end{array}$ & - & 1 & - & - & - & - & & 1 \\
\hline 5. & $\begin{array}{l}\text { Agreement } \\
\text { Maxim }\end{array}$ & 1 & 1 & 1 & 1 & 2 & 1 & - & 7 \\
\hline 6. & $\begin{array}{l}\text { Sympathy } \\
\text { Maxim }\end{array}$ & 1 & - & 1 & - & 1 & 1 & - & 4 \\
\hline & & & otal & & & & & & 52 \\
\hline
\end{tabular}

Table 2. The Percentage of Politeness

Principles Used by the Teacher

\begin{tabular}{|c|c|c|c|c|c|}
\hline No & Maxim & Marker & Example & Freq. & Percent \\
\hline 1. & Tact & $\begin{array}{l}\text { Commanding } \\
\text { indirectly } \\
\text { (using 'tolong' } \\
\text { or 'please') }\end{array}$ & $\begin{array}{l}\text { Fahri, tolong kamu } \\
\text { siapkan teman- } \\
\text { teman kelas kamu. } \\
\text { (Fahri, get your } \\
\text { classmates ready, } \\
\text { please.) }\end{array}$ & 18 & $34,62 \%$ \\
\hline 2. & Approbation & $\begin{array}{l}\text { Appreciating } \\
\text { student's } \\
\text { opinion } \\
\end{array}$ & $\begin{array}{l}\text { Yaah, very good, } \\
\text { headlines. }\end{array}$ & 16 & $30,77 \%$ \\
\hline 3. & Generosity & $\begin{array}{l}\text { Giving options } \\
\text { to students }\end{array}$ & $\begin{array}{l}\text { If you cannot find } \\
\text { the answer from } \\
\text { your textbook, } \\
\text { you can find from } \\
\text { another source, } \\
\text { such as from } \\
\text { internet. }\end{array}$ & 6 & $11,54 \%$ \\
\hline 4. & Modesty & $\begin{array}{l}\text { Pointing self- } \\
\text { limitation }\end{array}$ & $\begin{array}{l}\text { Mungkin } \\
\text { penjelasan Ibu } \\
\text { kepada kalian } \\
\text { masih kurang } \\
\text { cukup bagi kalian, } \\
\text { yah, itu karena } \\
\text { keterbatasan Ibu, } \\
\text { tapi kalian dapat } \\
\text { melengkapinya }\end{array}$ & 1 & $1,92 \%$ \\
\hline
\end{tabular}




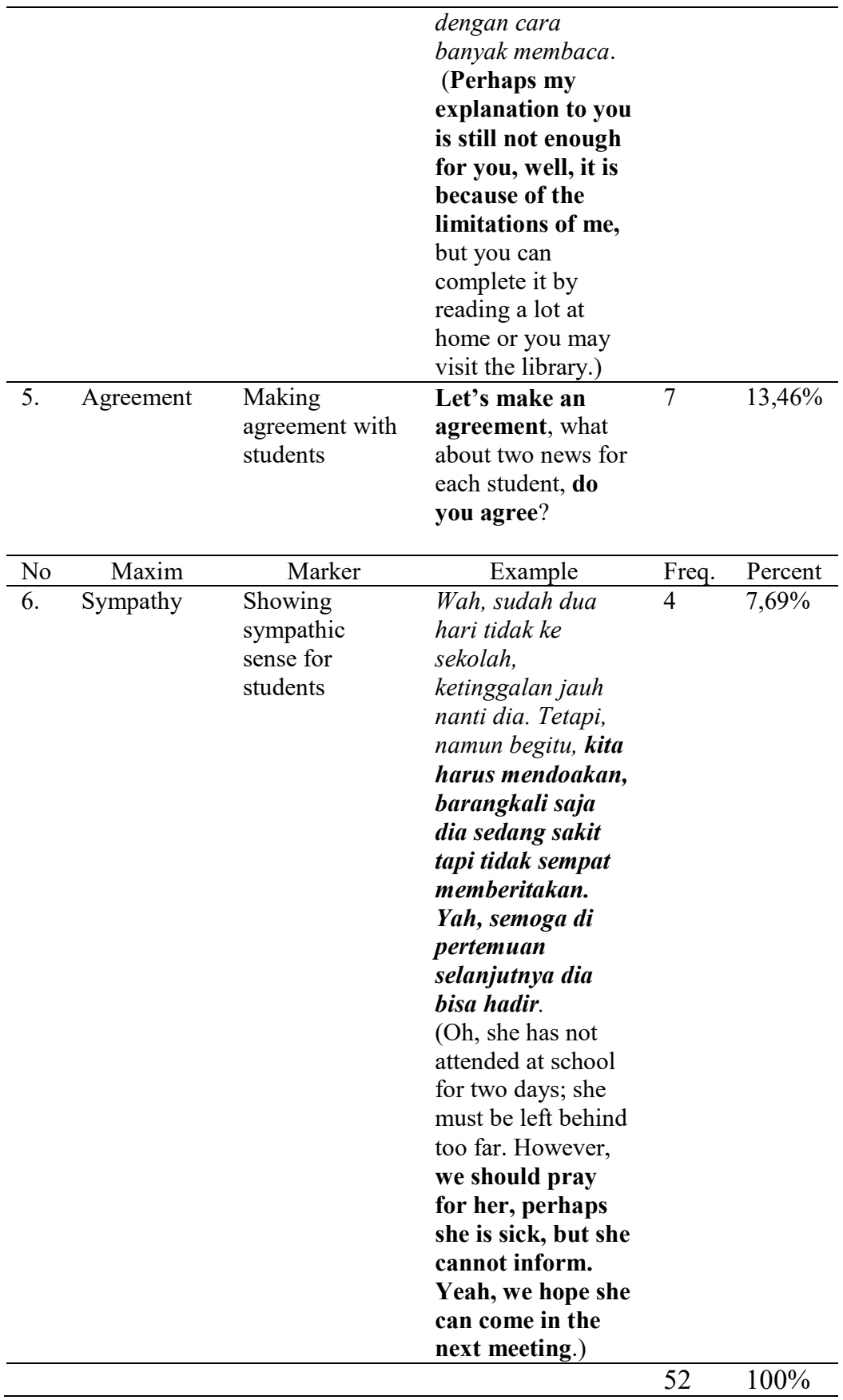


The table 1 shows the frequency of maxims occurred in teacher - students' interaction in EFL and table 2 reveals the percentage of maxims in teacher - students' interaction. Table 2 therefore indicates that, in the classroom interaction during seven meetings, tact maxim occurs in 18 utterances $(34,62 \%)$, approbation maxim occurs in 16 utterances $(30,77 \%)$, generosity maxim occurs in 6 utterances $(11,54 \%)$, modesty maxim occurs in 1 utterance $(1,92 \%)$, agreement maxim occurs in 7 utterances $(13,46 \%)$, and sympathy maxim occurs in 4 utterances $(7,69 \%)$.

\section{a. Tact Maxim}

Tact maxim is in two utterances in each of the first meetings, the third meeting, and the sixth meeting. In addition, three utterances at each of the second, the fourth, the fifth and seventh meeting. The teacher used tact maxim in his communication with the students because he wanted to reduce or minimize his own benefits and maximize the benefits for the students. Here is an example of how the teacher's politeness principle in terms of tact maxim arises when about to start a lesson.

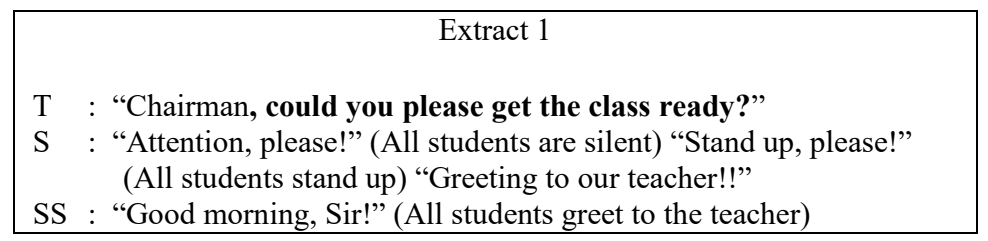

In this situation, the teacher asks the class leader to prepare his classmates indicating that the teacher is giving instruction. The teacher reveals her instructions indirectly showing her politeness by saying "could you please ....". By using such speech, the teacher tries to maximize the student's profit, using indirect sentences. This is categorized as tact maxim, in which the speaker tries to maximize the benefit of the listener or the speech partner.

\section{b. Approbation Maxim}

Approbation maxim appears three times at the first, fourth, and sixth meetings. Twice in each of the second, fifth, and seventh meetings. Next once at the third meeting. Teachers use the maxim of appreciation to appreciate students and to reward students.

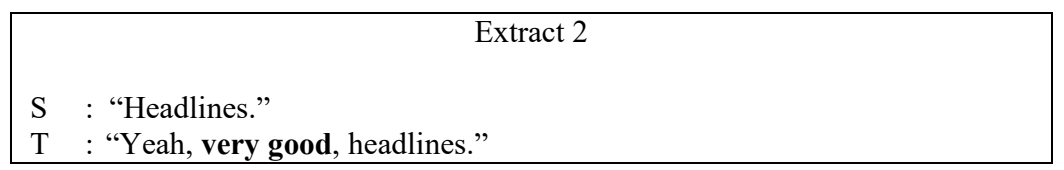

The teacher asks the students to think of some words or terms related to the newspaper. The students were then asked to name the words or terms they had thought. A student answers by saying "headlines," and the teacher appreciates or appreciates the answer by saying "very good."

\section{c. Generosity Maxim}

From the seven meetings observed by the researcher, it was found that there were six speeches of teachers who contained generosity maxims. Details, one 
utterance at each of the second and third meetings, then two utterances at each of the fourth and sixth meetings. An example can be seen in the following extract.

\section{Extract 3}

$\mathrm{T}$ : "Okay, let me write one word here, and after that, you continue by writing other words."

S : "Yes, Mam?"

In the extract above, the teacher asks the students to write the words related to the tree on the board. Because students have difficulties, the teacher is willing to help by writing a single word example. The teacher said "let me write one word here, and after that, you continue ...." Theoretically, the utterance is considered more polite because the teacher minimizes his own advantage, i.e., he is willing to help the student. In addition, in the utterance, there is a marker of politeness, which is "let me," so that it is a polite utterance.

\section{d. Modesty Maxim}

In seven meetings, the modesty maxim only appears once in the teacher's utterance. The teacher uses modesty maxim to show her own lack or not accentuate her strengths. The teacher's utterance that contains the modesty maxim can be seen in the following extract.

\begin{tabular}{|c|c|}
\hline Extract 4 \\
$\mathrm{~T} \quad$ : "Perhaps my explanation to you is still not enough for you, \\
well it's because of the limitations of me, but you can complete it \\
by reading a lot at home, or you may visit the library." \\
$\mathrm{S} \quad$ : "Yes, mam....." \\
$\mathrm{T} \quad$ : "Next meeting, there will be an examination or test for you."
\end{tabular}

In such situations, the teacher has given a material explanation and will end the lesson at the meeting that day. After giving some conclusions and reinforcement of the material, the teacher informs students about her explanations that are possibly still not very clear due to her limited ability. The teacher's point of self-limitation is the adoption of modesty maxim. In the teacher's speech, it appears that the teacher does not highlight her strengths, although in fact all the explanations are very clear and can be easily understood by the students.

\section{e. Agreement Maxim}

There are seven teacher's utterances that contain agreement maxim. One utterance at each of the first, second, third, fourth, and sixth encounters, and two utterances at the fifth meeting. The teacher uses the agreement maxim to show that the teacher agrees with the students so that the match between them is maximal. The following is the example of agreement maxim used by the teacher. 


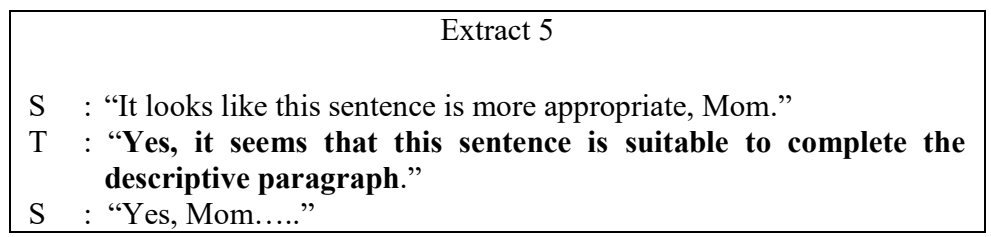

In this situation, the teacher and the students discuss a material, and then the teacher has expressed his own opinion. However, there is a student who politely declares that the teacher's opinion is inappropriate, and then expresses his or her own opinion which is more appropriate. The teacher accepts and agrees on the student's opinion about the choice of a more precise sentence. The declaration of justification is considered polite because the teacher agrees with the students so that a maximal fit exists between them.

\section{f. Sympathy Maxim}

The teacher used the sympathy maxim in four utterances. The four utterances are divided into one speech at the first, third, fifth, and sixth meetings. It can be seen in the following extract.

\begin{tabular}{|c|c|}
\hline \multicolumn{1}{|c|}{ Extract 6} \\
$\mathrm{~T} \quad$ : "I am so glad you can do your assignment well, I like your \\
seriousness."
\end{tabular}

From the above conversation, it is seen that the teacher expresses his joy because the students are serious in following the learning activity. As a result, they successfully complete their tasks very well. The expression of joy over the success of others includes the application of politeness in the case of sympathy maxim.

\section{The implication of politeness principle in learning teaching process}

From the results of interviews, the researcher found that the implications of the principle of politeness in the learning process impact on three aspects. The researcher found that the politeness principle creates an atmosphere of togetherness between teachers and students, builds respect for students, and helps students to have a positive attitude toward the lessons so that it motivates them to become more active in learning.

a. Politeness principle creates togetherness between teachers and students

From the interviews conducted with the EFL teacher of SMPN 23 Makassar, the researcher found that the politeness principle used by the teacher when interacting with students in the classroom could create togetherness between teacher and students. This is evident from the teacher's answer for the researcher's question, "As a teacher who often comes face to face with students both in the classroom and outside the classroom, by applying the politeness principle, what then do you feel about your relationship with your students?"

The teacher answered: 
"Yeah, Initially, I used to think, if I talk politely to them, they will belittle me, but in fact, not. I felt that when I asked and instructed them with polite speech, they got closer to me. I find that my politeness of speech draws students closer to me, and I see togetherness is also formed in the learning process."

The teacher said that her utterances had implications for creating a close relationship between the teacher and her students. Furthermore, the teacher also said that the atmosphere of togetherness between her and all students was formed in the learning process.

The teacher's statement above was supported by the answer of the students of grade VIII SMPN 23 Makassar when the researcher interviewed them. The researcher asked, "You have said that your English teacher is a teacher who always talks and behaves politely when educating in the classroom, then what effect do you feel on your relationship with your teacher?"

The student answered:

"Yaaa, how to say, eeee, because the teacher always talks wisely with us in class, so..., eee..., I feel close to him, There seems to be no estrangement, and then ..., $m m m \ldots$.. I feel there is togetherness with him in every meeting."

The student said that he felt no estrangement between him and his teacher. Furthermore, the student also said that there was an atmosphere of togetherness in learning when the teacher taught him. The answers of other students interviewed with the same question are similar to the students' answers above.

b. The principle of politeness builds student's respect behavior

The teacher was also interviewed with questions "When you give your students advice or direction with polite words, do you see that your students respect you?" The teacher replied by saying:

"Yes, of course, because all our speech acts will have a positive effect on the attitude of our students. I feel that, if the teacher speaks politely, commands wisely, care for all students, all students will respect the teacher, because they finally realize that the teacher is someone they should respect."

The teacher's statement indicates that, if a teacher talks or directs with polite words, all students will respect the teacher. It is in accordance with what the teacher feels. The results of interviews conducted to students also support the teacher's statement. An interviewee responded:

"I see some of my friends belittle teachers. But I myself increasingly respect the teacher who always advised me with polite words."

The student said that he was increasingly respectful to his teacher who always gives guidance and direction to him by using polite words.

c. Students are motivated to have a positive attitude toward the lesson

The results of interviews conducted to students indicate that the politeness principle applied by teachers helps students to have a positive attitude towards the lesson. As a result, they are increasingly motivated to participate more actively in learning activities. The researcher asked students, "How do you feel about English lessons related to your teacher's utterances in classroom interactions?". The student answered:

"Eeee, I used to hate English lessons because it was hard and confusing for me. But by way of my teacher in teaching, and her 
politeness in speaking, I suppose comfortable, I was so excited to learn English".

The student said that previously he did not like learning English because the lesson is very difficult for her. However, due to her teacher's way of teaching and her teacher's polite language, she became pleased with the English lesson. It makes the students more enthusiastic about learning activities. Other students also responded with similar answers, namely the politeness of the language used by the teacher makes them more motivated in following the lesson.

\section{Discussion}

Teacher's utterances containing the politeness principle have been classified into the types of maxims. The linguistic politeness principles used by the teacher are the tact maxim, approbation maxim, generosity maxim, modesty maxim, agreement maxim, and sympathy maxim. This is in accordance with the theory of the politeness principle put forward by Leech (1983).

The politeness principle applied by the teacher in classroom interaction creates the togetherness between teachers and students. This is in line with the theory put forward by Noddings (1995) and is also supported with the results of studies conducted by Limberg (2015) and Sülü (2015) that the politeness principle applied in classroom interaction can realize of efficient interaction between teachers and students.

Furthermore, the result of the interview also shows that politeness principle used by teachers when facing students in the classroom can build students' respect for teachers. In addition, it has implications for student learning motivation that makes them have a positive attitude towards the lesson so that they are more active in following the lesson. These implications are in line with what Achmad (2012) found in his research that the politeness principle in life has an impact on the realization of basic value conception. One of these basic values is the noble value, namely motivation and a positive attitude or view of something.

\section{Conclusions and Implications}

Based on the findings and discussion that have been presented previously, the conclusions of the research are: (1) In the classroom interaction Grade VIII of SMP Negeri 23 Makassar, the EFL teacher used six types of maxims or politeness principles, namely tact maxim, approbation maxim, generosity maxim, modesty maxim, agreement maxim, and sympathy maxim. (2) The politeness principle applied by the teacher in interacting with students has implications on three aspects. First, the politeness principle creates togetherness between teacher and students. Secondly, it builds students' respect. Furthermore, thirdly, the teacher's politeness principle helps students to have a positive attitude towards the lesson so that it motivates them to be more active in following the lesson.

Therefore, the researchers provide some implications regarding the results of this study. Firstly, the researchers suggest that teachers always apply the politeness principle in teaching and educating. This is because, in the classroom interaction or teaching-learning process, teacher's comparability has a significant influence on the process and learning outcomes. Furthermore, teachers should be able to control their utterances that contain the politeness principle in several types of conditions in the EFL class. This is because teachers become the center of attention of students in classroom interaction. In addition, the research on language politeness can not only be conducted in the field of teaching English but can also be done in other languages outside this research area. Thus, the results of this study can be used as a reference. Finally, for further research, researchers are recommended to investigate the deviation of the politeness principle by teachers and students in English learning. 


\section{Bibliographic references}

ACHMAD, S. 2012. Strategi Kesopanan Berbahasa Masyarakat Bugis Pinrang Provinsi Sulawesi Selatan. Bahasa dan Seni, 40(1), 1-13. ISSN: 0854-8277/e-ISSN 2550-0635

AUSTIN, J. L. 1962. How to Do Things with Word (2nd ed.). Oxfod: Oxfod University Press. ISBN: 9780674411524.

BROWN, P. - LEVINSON, S. 1987. Politeness: Some Universals in Language Usage. Cambridge: Cambridge University Press. ISBN: 0521313554, 9780521313551.

ESHGHINEJAD, S - MOINI, M. R. 2016. Politeness Strategies Used in Text Messaging: Pragmatic Competence in an Asymmetrical Power Relation of TeacherStudent. SAGE Open, 6(1). doi: 10.1177/2158244016632288. ISSN: 2158-2440/ Online ISSN: 2158-2440.

GREENFIELD, L. 1972. Situational Measures of Normative Language Views in Relation to Person, Place, and Topic Among Puerto Rican Bilinguals. In J. A. Fishman (Ed.), Advances in the Sociology of Language (Vol. 2). Mouton: The Hague. HYLAND, K - PALTRIDGE, B. 2011. Continuum Companion to Discourse Analysis. New York: Continuum International Publishing Group. ISBN: 9781441165640.

JUFRI, M - HARYANTO - WEDA, S. 2015. Enhancing Vocabulary Mastery of the Second Year Students of SMA Muhammadiyah 1 Unismuh Makassar through Word Wall Strategy. Thesis Article. State University of Makassar. Makassar.

KAWAI, M. 2013. The Application of Politeness Theory into English Education in Japan. (Published Thesis), Linköping University, Linköping.

KIYAMA, S. - TAMOKA, K - TAKIURA, M. 2012. Applicability of Brown and Levinson's Politeness Theory to a Non-Western Culture: Evidence From Japanese Facework Behaviors. SAGE Open, 2(4). doi: 10.1177/2158244012470116. ISSN: 2158-2440/ Online ISSN: 2158-2440.

KURNIAWATI, OKTAFINA. 2012. Analisis Pemanfaatan Prinsip Kesantunan Berbahasa pada Kegiatan Diskusi Kelas Siswa Kelas XI SMA N 1 Sleman. (Upublished Thesis), Universitas Negeri Yogyakarta, Yogyakarta.

LAKOFF, R. 1973. The Logic of Politeness: or, Minding your p's and q's. In C. Corum, T. C. Smith-Stark - A. Weiser (Eds.), Papers from the Ninth Regional Meeting of the Chicago Linguistic Society (pp. 345-356). Chicago: Chicago Linguistic Society. ISSN: 0577-7240.

LEECH, G. 1983. Principles of Pragmatics. New York: Longman Inc.

LEVINSON, S. C. 1983. Pragmatics. Great Britain: Cambridge University Press.

LIMBERG, H. 2015. Teaching how to apologize: EFL textbooks and pragmatic input. Language Teaching Research, 20(6), 700-718. doi: 10.1177/1362168815590695

MCMOHAN, A. 1994. Understanding Language Change. New York: Cambridge University Press.

MILES, M. B. - HUBERMAN, A. M. 1994. Qualitative Data Analysis: An Expanded Sourcebook (2nd ed.). Thousand Oaks CA: Sage Publication. ISBN: 0803955405, 9780803955400 .

MOLEONG, L. 2008. Metode Penelitian Kualitatif. Bandung: Rosda Karya. ISBN: 978-514-051-5

NASHRUDDIN. 2017. Politeness Principles Used by EFL Teacher in Classroom Interaction and Its Implication toward Teaching-Learning Process. Unpublished Master Thesis, State University of Makassar, Makassar.

NODDINGS, N. 1995. Philosophy of Education. Colorado: Westview Press, Inc. ISBN: 978-0813345314.

PITTS, M.J. - FOWLER, C. - FISHER, C.L - SMITH, S.A. 2013. Politeness Strategies in Imagined Conversation Openers About Eldercare. Journal of Language

XLinguae, Volume 11, Issue 4, October 2018, ISSN 1337-8384, eISSN 2453-711X 
and Social Psychology, 33(1), 29-48. doi: 10.1177/0261927x13506708. ISSN 0261927X/Online ISSN: 1552-6526

PRINSIP KESANTUNAN BERBAHASA. Available online: http://www.scribd.com/doc/14548085/pragmatik.

SAFITRI, KURNIA. 2014. Penyimpangan Prinsip Kesantunan Berbahasa dalam Interaksi Belajar Mengajar Bahasa Indonesia Siswa Kelas VIII SMP Negeri 3 Sewon. Unpublished Thesis Universitas Negeri Yogyakarta.

STRIKE, K. A. - EGAN, K. 1978. Ethics and Educational Policy. London: Routledge \& Kegan Paul Ltd. ISBN 978-0415647571

SÜLÜ, A. 2015. Teacher's Politeness in EFL Class. International Online Journal of Education and Teaching (IOJET), 2(4), 216-221. ISSN 2148-225X

ULFA, Z. - ATMOWARDOYO, H. - MAHMUD, MURNI. 2015. Teacher's Verbal Politeness Strategies in EFL Classroom. Thesis Article. State University of Makassar. Makassar.

Words: 6109

Characters: 39220 (21,79 standard pages)

prof. Dr. Haryanto, M.Pd.

English Department

Universitas Negeri Makassar

Jl. Dg. Tata, Kampus UNM Parangtambung Makassar

Indonesia

aharyanto_fbsunm@yahoo.co.id

assoc. prof. Dr. Sukardi Weda, S.S., M.Hum., M.Pd., M.Si., M.M., M.Sos.I., M.A.P.

English Department

Universitas Negeri Makassar

Jl. Dg. Tata, Kampus UNM Parangtambung Makassar

Indonesia

sukardi.weda@unm.ac.id

Nashruddin, S.Pd., M.Pd.

STKIP Muhammadiyah Enrekang

Jl. Jenderal Sudirman, Galonta, Kec. Enrekang

Kabupaten Enrekang Sulawesi Selatan

nashruddinleghx@gmail.com 